\title{
Research on the Influence of Corporate Governance Structure on the Performance of Nepal Commercial Banks
}

Amit Kumar Gupta* and Gao Xin Wei

Department of Applied economics, China University of Petroleum Huadong, China

\begin{abstract}
The current researches portray the corporate governance's variables on non-performing loan of commercial bank in Nepal. The total assists of the bank depend on the dependent variables of are non-performing loan and nonperforming loan to total assets while the independent variables includes i.e. board size, independent directors, audit committee member, foreign ownership, domestic ownership, CEO duality, bank age, female director, board meeting and bank size. So the study conducted in current research is based on the data obtained from eighteen commercial banks in Nepal dated: $2010 / 2011$ to $2015 / 2016$, leading to a total of 108 observations. Some of the data were obtained from websites and annual reports of the Nepalese Banks. The data were analysed through regression model to examine the importance of corporate governance variables on non-performing loan. Some of the result has positive correlation with the ratio of non-performance loan which shows that diversified the board, director of board, audit committee higher will be the ratio of nonperforming loan and vice versa, while the result has negative impact on the presence of foreign ownership which are otherwise explain the presence of foreign of ownership would reduce the bank proficiency. Furthermore the presence of domestic ownership has increased the efficiency of the corporate banking sectors. The presence of dual CEO is also negative relation with the performance of the bank. Similarly the age of bank, presence of female director, number of board meeting and bank size has positive relation with the said topic.
\end{abstract}

Keywords: Corporate governance; Independent director; Nonperforming loan; CEO duality; Foreign ownership; Domestic ownership; Audit committee member; Female director

\section{Introduction}

The corporate finance has become popular in the recent decades since from the Asian financial and WorldCom scandals. The main cause of such notorious issues linked to the poor corporate finance. The corporate governance is thought to be the critical factor for performance of firm, capital allocation and risk management of the business and most important for its business customers [1]. Corporate governance is the key to the global integrity of corporate institutions especially financial institutions and other sectors. It cannot occur in the absence of accountability and transparency. These two brings development, growth and lasting corporate performance in monetary and operational terms. For this reason, the quality of corporate governance principles in place affects the performance of individual institution and that of the economy as a whole in terms of growth and development. The impact of corporate governance on firm performance has received enormous attention in economic and finance literature in recent years. This attention has been motivated by financial scandals that rocked the U.S. economy in early and late 2000 and the Asian financial crisis of late 90 s. Despite a number of studies having been undertaken on the subject matter, there is still much debate on the relationship between corporate governance and firm performance and more soon the relationship between corporate governance and performance of commercial banks [2]. Banking play a critical role in the economy of an country as described from the 1997-98 Asian economic crises which highlighted the importance of said sectors. The corporate is important and more precious than other industry of the country because poor or bad corporate sector make the market miserable and lose of confidant [3]. In contrast, good corporate governance strengthens property rights; minimize transaction cost and the cost of capital, and leads to capital market development. Corporate finance is look to be the measure of the whole scenario of the economic growth of the country [4-6]. The role of director or manager are discussed in agency theror by previous litterateur i.e. Jensen [4], Padilla [7]; Clark, [8]; Tornyeva and
Wereko [5] while the Steward theory are generated from the work of the Donaldson and Davis, 1991; Schoorman and Donaldson, Tornyeva and Wereko, [5] These theories strongly consider that the work in team is better than work as individual i.e. cooperative vs individualistic behavior. While the resource dependency theory shows the importance of role performed by the director in providing access to all the living and non-living resources [5]. This theory is based to focused on essential resource to the company in the firm of information, skills, access to key constituents such as suppliers, buyers, public, policy maker, social group as well as legitimacy. And all these resources are need to be linked because a good organizational works always need team efforts; it mean that the actions of the organization is significantly effect the financial performance each others eithers positively or negatively as a whole [5]. Therefore, it is the needs of the day to develop the organization relationship at high and low levels in the corporate sectors. According to Johnson et al. [9] the theory provide focus on the appointment of representatives of independent organizations as a means of gaining accessibility to resources critical to the organizations success [5]. The stockholder theory define the accountability to stake holder than share holder [10]. Furthermore the said theory believe on the good fruitful relation of manager with different individuals of various filed like suppliers, employees and business partner and it was argued that this group of network is important other than ownermanager-employee relationship as in agency theory. Both stakeholder

*Corresponding author: Amit Kumar Gupta, Department of Applied economics, China University of Petroleum Huadong, China, Tel: 008613465832870; E-mail: amitkumargupta498@yahoo.com

Received November 13, 2018; Accepted December 11, 2018; Published December 17, 2018

Citation: Gupta AK, Wei GX (2018) Research on the Influence of Corporate Governance Structure on the Performance of Nepal Commercial Banks. J Glob Econ 6: 316. doi: 10.4172/2375-4389.1000316

Copyright: $\odot 2018$ Gupta AK, et al. This is an open-access article distributed under the terms of the Creative Commons Attribution License, which permits unrestricted use, distribution, and reproduction in any medium, provided the original author and source are credited. 
and dependency theory suggests the representation of different interest group in the board of governor in order to avoids conflict of interest and consensus of benefits. So the board of governor serves as a bridge to resolve issues and brought things of mutual interests and organizational benefits. Despites of all its good feature some previous literature such as Jensen [10] criticized the theory. According to him the progress of an organization is not only shown by returns to stakeholders but equally significant by the management organizational information, with inter-personal relationships in the organization and the working environment. As a nature of complex nature of the stakeholder relationship and the need for the better management of the various stakeholders, Donaldson and Preston [11] have concluded that stakeholder theory cannot be a single theory but divided them into three different approaches of descriptive, instrumental and normative.

In case of the Nepal, the reforms in corporate bank governance are highly important to achieve persistent efforts to attract worthy foreign investments directly with management of different portfolio and to achieve the goal of saving through market capitals. The central bank of Nepal diagnosed severe lapses in corporate bank governance in every bank of Napel, despite being issue the important directives to empowered the corporate bank governance in 2005, the result were not up to the marks. So the objectives of this research are to fill a gap as the first in-depth study in the role of corporate governance in efficiency of Nepalese commercial banks. Furthermore the outcomes of current research are in coherence with the previous studies conducted in different parts of the world [3]. The study is unique in Nepal and rare in the world mainly emphasis of corporate structures and strategies that will in turn affect their performance. The above discussion shows that there is no constancy in the findings of different studies concerning capital adequacy, cost income and banks performance. Therefore, current research has shown the effect of capital adequacy and cost income on the performance of banks. While more exactly, it tests the effects of capital adequacy ratio, cost income ratio, debt to equity ratio, equity capital to assets, bank size and liquid ratio on the performance.

\section{Methodological Aspects}

The current study is rely on the secondary data obtained from Nepal banks, the total number of banks are eighteen and time duration ranges from $2010 / 11$ to $2015 / 16$. The total observation obtained from the banks data are 108 .

Table 1 shows the number of commercial banks selected for the study along with the study period and number of observations

The model estimated in this study assumes that the non-performing loan depends on the several corporate governance variables. The corporate governance variables include board size, independent director, audit committee member, domestic ownership, female director, board meeting, bank age, and foreign ownership and CEO duality. Therefore the model takes the following form:

Efficiency $(\mathrm{EY})=f$ (Board size, Number of independent director on the board, Number of audit committee member, Foreign ownership, Domestic ownership, CEO duality, Bank age, Number of female director in the board, Number of board meetings, Bank size)

More specifically, the given model has been segmented into following models:

\section{Model 1}

Non performing loan $=\beta_{0}+\beta_{1} \mathrm{BS}+\beta_{2} \mathrm{ID}+\beta_{3} \mathrm{ACM}+\beta_{4} \mathrm{FO}+\beta_{5} \mathrm{DO}+\beta_{6} \mathrm{CE}$ $\mathrm{OD}+\beta_{7} \mathrm{BA}+\beta_{8} \mathrm{FD}+\beta 9 \mathrm{BM}+\beta 10 \mathrm{BAS}+\varepsilon$ it

\begin{tabular}{|c|c|c|c|}
\hline S. No. & Name of Commercial Banks & Study period & Observations \\
\hline 1 & $\begin{array}{l}\text { Agriculture development bank } \\
\text { limited }\end{array}$ & $2010 / 11$ to $2015 / 16$ & 6 \\
\hline 2 & Nabil bank limited & $2010 / 11$ to $2015 / 16$ & 6 \\
\hline 3 & Nepal investment bank limited & $2010 / 11$ to $2015 / 16$ & 6 \\
\hline 4 & $\begin{array}{l}\text { Standard chartered bank nepal } \\
\text { limited }\end{array}$ & $2010 / 11$ to $2015 / 16$ & 6 \\
\hline 5 & Himalayan bank limited & $2010 / 11$ to $2015 / 16$ & 6 \\
\hline 6 & Nepal SBI bank & $2010 / 11$ to $2015 / 16$ & 6 \\
\hline 7 & Everest bank limited & $2010 / 11$ to $2015 / 16$ & 6 \\
\hline 8 & Kumari bank limited & $2010 / 11$ to $2015 / 16$ & 6 \\
\hline 9 & Bank of Kathmandu limited & $2010 / 11$ to $2015 / 16$ & 6 \\
\hline 10 & Laxmi bank limited & $2010 / 11$ to $2015 / 16$ & 6 \\
\hline 11 & Citizens bank international limited & $2010 / 11$ to $2015 / 16$ & 6 \\
\hline 12 & Prime commercial bank limited & $2010 / 11$ to $2015 / 16$ & 6 \\
\hline 13 & Sunrise bank limited & $2010 / 11$ to $2015 / 16$ & 6 \\
\hline 14 & NMB bank Nepal limited & $2010 / 11$ to $2015 / 16$ & 6 \\
\hline 15 & NIC Asia bank limited & $2010 / 11$ to $2015 / 16$ & 6 \\
\hline 16 & Machhapuchchhre bank limited & $2010 / 11$ to $2015 / 16$ & 6 \\
\hline 17 & Sanima bank limited & $2010 / 11$ to $2015 / 16$ & 6 \\
\hline 18 & Siddhartha bank limited & $2010 / 11$ to $2015 / 16$ & 6 \\
\hline \multicolumn{2}{|r|}{ Total number of observations } & & 108 \\
\hline
\end{tabular}

Table 1: List of sample banks selected for the study alone with the study period and number of observations.

Model 2 cost efficiency $=\beta 0+\beta 1 \mathrm{BS}+\beta 2 \mathrm{ID}+\beta 3 \mathrm{ACM}+\beta 4 \mathrm{FO}+\beta 5 \mathrm{DO}+$ $\beta 6 \mathrm{CEOD}+\beta 7 \mathrm{BA}+\beta 8 \mathrm{FD}+\beta 9 \mathrm{BM}+\beta_{10} \mathrm{BAS}+\varepsilon_{\mathrm{it}}$

Where,

$\mathrm{EY}=\mathrm{E} f \mathrm{ficiency}$ is defined as the ratio of non-performing loan to total loan.

$\mathrm{CE}=$ cost efficiencyis defined as the ratio of total operating expenses to total assets.

$\mathrm{BS}=$ Board size is defined as the members of directors in the board.

ID=Independent Directors is defined as the number of independent director on the board.

$\mathrm{ACM}=$ Audit committee is defined as the number of audit committee members.

$\mathrm{FO}=$ Foreign ownership is defined as the proportion of foreign ownership in the firm.

$\mathrm{DO}=$ Domestic ownership is defined as the proportion of domestic ownership in the firm. CEOD=CEO duality is defined as the combination of responsibility of board chairperson and

CEO, ' 0 ' for the different role of CEO and chairman, ' 1 ' otherwise. $\mathrm{BA}=\mathrm{Bank}$ ageis defined as duration of operation till current year.

$\mathrm{FD}=$ Female directors is defined as the number of female directors in the board.

$\mathrm{BM}=$ Board meeting is defined as the number of board meetings held in the given year. BAS=Bank sizeis defined as total assets of the bank.

\section{Nonperforming loans}

Non-performing loans (NPLS) generally refer to loans which for a relatively long period of time do not generate income; that is, the principal and/or interest on these loans have been left unpaid for at least ninety (90) days. According to the Kiger that when specific items of less or poor credits administration i.e. liberal credits loose, poor 
quality of management, poor follow up subsists, and a tendency for credit to go in bad way. In Nigeria, NPLs are not new and have been in operations since late 1980, but became more pronounced in 1980 as they were the single most devastating cause of banks failure. For example, in 1998 when 26 banks were liquidated in one fell swoop, CBN reported that the NPL for the banks was N101 billion. The distressed banks" outstanding credits alone was N33 billion or $7.8 \%$ of the total credits, while provision for NPL stood at N64.5 billion. The NPL ratio in the industry then was $24.4 \%$.

\section{Board size}

The agency theory assumes that smaller board is recommended to minimize the agency cost by effective control over the management whereas larger boards might increase a large number of potential interactions and conflicts among the group members [12]. According the Bussoli [13] the relationship between corporate governance and banks loans performance are empirically stated that board size of any bank is negatively influence the quality of loans and resulted in higher nonperforming loans. While according to Maria et al. [14] and others the effect of board size and composition on the banking efficiency empirically stated that higher the board size less the efficiency of the banks [14-17].Conversely another school of thoughts believe on larger boarder size more efficiency of the bank sector [18] while some author believe that the numbers of member in board are supposed to be seven or eight [19]. While in case of Nepal the board of governor/director the numbers of members consists of 5 to 9 in which the idea was taken from the works of Lipton and Lorsch, [20]. Meanwhile some author suggests that relationship between board size and firm performance is positive [21]. However, according to the Ghabayen [22] it is stated that no relationship between board size and a firm's performance. Moreover, if performance is measure in ROA and ROE the impact of board size have positive significant with firm performance.

\section{$\mathbf{H}_{1}$ : There is a negative relationship between board size and efficiency}

\section{Board independence}

The empirical findings on board independence and bank performance have been mixed. Prior studies show that a majority of independent directors are necessary for better bank governance [22].Previous literature stated that the status higher the board independence, higher efficiency and vice versa [23-27]. It shows that independent directors are protect the shareholders right to let realize the importance of outside directors on board. According to Anderson [18] there is an overturned U-shaped relative among outsider and bank performance. In current study it is highlight that an independent board of directors has less conflicts of interest when monitoring managers. Thus, when the monitoring function is predominant, we imagine that adding new sovereign managers to the board which will progress the regulation of management and decreases the conflict of interest among stakeholders, but numerous independent directors will abolish bank worth because of the problems such as coordination and decisionmaking. According to this, it might have an best mix of executive and independent directors at a point, which is more adequate to create value for the banks than excessively independent boards. Thus, based on the above, the following hypothesis is examined:

$\mathbf{H}_{2}$ : There is positive relationship between board independence and bank efficiency.

Number of audit committee member

The main role of audit committee is to increase the excellence of the finance which leads to enhace the performance of firm [28-30]. The Cadbury Commission proposed that at least three members constitute the audit committee. It is likely said that larger the volume of audit committee have much better resources than smaller audit committee. From the previous literature it is clear that the members of the audit committee increase has increased the activity substantially group performance and decrease the chance for wrong doing difficult [31]. The degree to which audit clients was confronted with agency conflicts influence their choice of audit quality. The said literature also show the negative effect of audit committee on the performance of bank is credited to the members of audit committee and lack of experience in helping the board in the bank of governance. So there is mixed result regarding audit committee size and performance of firm. While the same literature believe the positive relation while some show no relation exists between audit committee and bank performance [32-35].

$\mathbf{H}_{3}$ : There is a positive relationship between the size of the audit committee and bank efficiency.

\section{Foreign ownership}

The foreign ownership has a positive impression on banks' soundness. According Levine [36] the foreign shareholding increases the supply and the quality of financial services, improves the complete administrative situation and eases the entrance to international financial global markets. According to Brealey a nd Kaplanis [37] the presence of foreigner in board of governor in banks increases directly foreign investment in the non-financial sector. Besides the foreign ownership it also increases human assets through the existence of foreign managers which convey good skills and technology [38] The international experience will also lead to progress the local competencies through training and knowledge transfer. While Barth et al. [39] found a negative effect of foreign ownership on NPLs on a cross countries analysis. They focus that foreign banks increase loan quality in a country and may lead to expand domestic banks credit quality. While according to Boubakri et al. [40] foreign participation decreases the level of risk taking between banks on a sample of 81 banks from 22 developing countries. Finally Micco et al. [41] said that foreign organized banks are more preformat than domestic ones bank for a panel of developing countries [42]. There are various previous literatures on the relationship between ownership and bank profitability. So it is clear that the foreign ownership shows vital role in a performance of firm, chiefly in rising and transitional economic of countries [43]. The said researches were taken on the industrial and developing countries [44]. While according to Clarke et al. [45] the foreign banks are more profitable than domestic one in developing countries and less profitable in industrial countries.

$\mathbf{H}_{4}$ : There is a positive relationship between foreign ownership and bank efficiency.

\section{Domestic ownership}

Increased domestic ownership (DO) presence adversely affects capital allocation efficiency. Increases in DO are associated with increased lending to less productive economic sectors and to industries that are not dependent on external finance, suggesting a misallocation of funds by domestic shareholder-controlled banks. These findings are consistent with the looting view, a pessimistic assessment of related lending practices by banks [46].The main findings from the study is the domestic ownership have a significant impact on bank's performance and non-performing loan [30]. The Large domestic shareholders of banks (e.g. local companies, wealthy individuals) typically have 
substantial interests in nonfinancial firms as well; banks controlled by these domestic shareholders usually direct a significant portion of their lending activities to related parties (e.g. firms controlled by relatives), even when these firms are inefficient. Porta et al. [46] observed that developing countries with poor governance could adversely affect capital allocation efficiency.

$\mathbf{H}_{5}$ : There is a negative relationship between domestic ownership and bank efficiency.

\section{CEO duality}

The board of governor is used, for strategic decision making and setting organizational vision Moreover, agency theorists was put forward in order to monitoring feature which is the separation between the roles of the CEO and chairman [47]. According to El-Chaarani [48] found that there is a prominent and negative relationship exists among CEO duality and bank performance. Furthermore Daily and Dalton [49] clarified that duality may light the board's ability to watch for executive opportunism. Moreover, agency theorist claims that a powerful leader holding both the CEO and board chairman positions will tend to pursue his personal interests more willingly than for the benefit of the principal. An individual with dual positions will tend to operate ceremonially, communicate poorly and "rubber-stamp" the executive's verdicts [50]. On the other hand, the separation of CEO and chairman positions shows positive signals to corporate lenders and investors. Hence, raises the probabilities of nurturing extra capital that decreases the menace of bankruptcy [51]. Ehikioya and Benjamin [52] discovered that for firms, in which their $\mathrm{CEO}$ and Board chairman are separated, stakeholders are likely to gain confidence in the firms' ability to raise additional capital; and hence, there are less chances of bankruptcy.

$\mathbf{H}_{6}$ : There is a positive relationship between $\mathrm{CEO}$ duality and bank efficiency.

\section{Bank age}

As the firms grow in age, it is expected to gain an experience in the production processes, handling with customers, understanding needs of employees, and adopting with whole stakeholders. In studying the relationship between firm age and profitability, we want to differentiate that possible influence of age on profitability through going back to the previous studies. Segarra et al. [53] found evidence that firms improve with age, because ageing firms are observed to have steadily increasing levels of productivity and higher profits. While most of the studies proved the existence of a significant negative relationship between age and profitability like: Bank age, duration of the loan, and credit policy were found to be significant determinants of NPLs [54].Other studies also concluded no significant relationship between age and profitability like [55]. But the nature of banks may be different somehow, because as bank grows in age, it gains the customer loyalty, and benefits from the experience curve, so the seventh hypothesis is stated as follows:

$\mathbf{H}_{7}$ : There is a significant positive correlation between the bank age and its efficiency.

\section{Female directors}

From an agency theory perspective, suggested that "women (like external shareholders, ethnic minorities, and foreigners) often bring a fresh perspective on complex issues, and this can help correct informational biases in strategy formation and problem solving." Adams and Funk [56] provided evidence that generalizing from the population to the executive ranks may be misleading. In a survey of the population of directors in Sweden, they show that women on boards of publicly-listed firms are different both from women in the general population and from male directors in the values they emphasize. Female directors are more open to change and less conservation oriented than both their population counterparts and male directors. A resent Finnish study reports that female board members are, compared to their male counterpart, more likely to take active role on their boards [57]. Resource dependency theory is a second guiding perspective as female directors bring exclusive and prized resources and connection to their boards. In the case of systems, early work exposed that compare to male managers; female managers normally have more various systems [58]. According gender role theory Eagly [59] proposed that a discrete gender defines his/her conduct and its efficiency with respect to inspiration. Furthermore, the theory proposes that male and female actions are measured in terms how it attributes (or diverges) from prospects of the relevant sex. Individuals who use strategies that are associated to their gender incline to be perceived better by others such as women are estimated to assign to more womanly characters i.e. kindness and courtesy [60]. By contract men are probable to be more assertive and violent. Another gender role related with women is flexibility which leads to greater ability to handle vague circumstances [61]. The researcher established that the gender of a co-op bank president had important influence on the bank's efficiency and when that position was detained by a woman officer, this condition had a encouraging effect on the bank's condition which indicates a positive association among the board gender variety and firm performance [62].

$\mathbf{H}_{8}:$ There is a positive relationship between female director and bank efficiency.

\section{Number of board meeting}

CAR and NPL are not statistically significant relationship between board meeting [63]. Author suggested that the board meeting be important resource in improving the effectiveness of the board. It helps directors to be informed and keep abreast with the development with the organization [64]. Regular meetings also allow directors to sit and strategize on how to move the organization forward. Lipton and Lorsch [20] revealed that the regular meetings enable directors to interact thereby creating and strengthening cohesive bonds among them. However, the opposing view of board meetings is that it is costly in terms of travel expenses, refreshments and sitting allowance to be paid to directors Board meetings are not necessarily useful because the limited time outside directors meet is not used for meaningful exchange of ideas among themselves and management Jensen [65] instead preoccupied with routine tasks and meetings formalities. This reduces the amount of time the board has to monitor management [20,66-68].

$\mathbf{H}_{\mathbf{9}}$ : There is a positivelyand significantly relationship between the board meetings and bank efficiency.

\section{Bank size}

Pandey [66] defined the size of the organization in form that assets that it holds. Large firms are less disposed to insolvency; this is because such firms have diversified their investment segments and hence lower their risks. Hauner [68] found that relationship between bank size and efficiency is positive. Pasiouras et al. [67] also showed that size of the bank is positively associated with bank's cost efficiency. Low levels of bankruptcy allow larger firms to access high amounts of debt. Large firms may reduce the level of information asymmetry in the market by taking advantage of opportunities in the market that enhances 
performance. Large firms are more stable as compared to smaller firms they have capacity to satisfy their financial duties and hence have a high degree of information exposure [69]. Large banks meet the customers' financial demands as a result of their wide network of branches; this has a greater impact on large banks as compared to small banks that do not service these markets. Authors argued that efficiencies induced by bank growth are determined by bank size because economies of scale differ based on a range of possible sizes of bank operations. Larger firms have better market experiences and well defined networks and hence stand a better chance as compared to younger that are still struggling to establish themselves in the market. Ammar and Russell [70] assessed the factors that affected profitability of a bank prior and during the financial crisis that faced Switzerland. The results found that both large and small banks were positively related to profitability. Further, it was unravelled that big and smaller banks were profitable compared to medium-sized banks prior the crises. One of the reasons given why larger banks were profitable was because they had more efficient services since they adopted modern technologies. The banks had diversified their products and services to minimize risks, by handling bulky products and services and having complex systems and processes enabled the banks to enjoy economies of scale.

$\mathbf{H}_{10}$ : There is a positive relationship between bank size and bank efficiency.

\section{Result and Discussion}

Table 2 presents the descriptive statistics of selected dependent and independent variables during the period 2010/11 to 2015/16.

Table 2 presents the descriptive statistics of selected dependent and independent variables during the period 2010/11 to 2015/16. Dependent variables are NPL (non-performing loans is defined as non-performing loan divided by total loan), NPL/TA (non-performing loan to total assets is defined as non-performing loan divided by total assets) and independent variables are BS (board size is defined as numbers of board members in a commercial bank), BM (board meeting is defined as numbers of board meeting held in a year), ID (independent directors is define as the number of independent director in the board), CEOD (CEO duality is define as the combination of responsibility of board chairperson and CEO), BA (Bank age is defined as duration of operation till current year), FO (foreign ownership is defined as percentage of ownership occupied by foreign investors), DO (domestic ownership is define by percentage of ownership occupied by national investors), ACM (composition of audit committee is defined as numbers of members formed from different wings of bank in audit committee), BAS (Bank size is defined as total assets of the bank),

\begin{tabular}{|c|c|c|c|c|}
\hline & Minimum & Maximum & Mean & Std. Deviation \\
\hline CE & 0.023 & 0.655 & 0.08782 & 0.101749 \\
\hline NPL & 0 & 8.6 & 1.817 & 1.627 \\
\hline BS & 5 & 11 & 7.907 & 1.3152 \\
\hline ID & 1 & 4 & 2.343 & 0.8446 \\
\hline ACM & 2 & 5 & 3.546 & 0.7154 \\
\hline FO & 0 & 75 & 12.939 & 22.593 \\
\hline DO & 25 & 100 & 87.061 & 22.593 \\
\hline CEOD & 0 & 1 & 0.056 & 0.2301 \\
\hline BA & 3 & 48 & 17.167 & 10.2086 \\
\hline FD & 0 & 2 & 0.343 & 0.6139 \\
\hline BM & 6 & 56 & 17.648 & 8.9967 \\
\hline BAS & 2.12 & 127.3 & 48.65844 & 27.47607 \\
\hline
\end{tabular}

$\mathrm{BM}$ (board meeting is defined as the number of board meeting held in the given year), FD (female directors is defined as the number of female director in the board).

The board size ranges from minimum 5 directors to the maximum of 11 directors leading to the average director of 7.907. The independent directors range from minimum 1 director to the maximum of 4 directors leading to the average director of 2.343 . The audit committee members range from minimum 2 members to the maximum of 5 members leading to the average member of 3.546. The foreign ownership ranges from minimum 0 percent to the maximum of 75 percent leading to the average percent of 12.939. The domestic ownership ranges from minimum 25 percent to the maximum of 100percent leading to the average of 86.135 percent. The CEO duality ranges from minimum 0to the maximum of 1 leading to the average of 0.056 . The bank age ranges from minimum 3years to the maximum of 48 years leading to the average years of 17.167. The female directors range from minimum 0directors to the maximum of 2 directors leading to the average director of 0.343 . The board meeting ranges from minimum 6 meetings to the maximum of 56meetings leading to the average meetings of 17.648 . The bank size ranges from minimum 2.12 to the maximum of 129.78 leading to the average of 49.112 .

\section{Correlation analysis}

Having indicated the descriptive statistics, Pearson correlation coefficients are computed and the results are presented in Table 3 . (The results are based on panel data of 18 banks with 108 observations during the period 2010/11 to 2015/16, by using regression model. The model is, Efficiency $(\mathrm{EY})=\beta_{0}+\beta_{1} \mathrm{BS}+\beta 2 \mathrm{ID}+\beta 3 \mathrm{ACM}+\beta 4 \mathrm{FO}+\beta 5 \mathrm{DO}+$ $\beta 6 \mathrm{CEOD}+\beta 7 \mathrm{BA}+\beta 8 \mathrm{FD}+\beta 9 \mathrm{BM}+\beta 10 \mathrm{BAS}+\varepsilon$ it. Where, independent variables are $B S$ (board size is defined as numbers of board members in a commercial bank), BM (board meeting is defined as numbers of board meeting held in a year), ID(independent directors is define as the number of independent director in the board),CEOD (CEO duality is define as the combination of responsibility of board chairperson and CEO), BAS (Bank age is defined as duration of operation till current year), FO (foreign ownership is defined as percentage of ownership occupied by foreign investors), $D O$ (domestic ownership is define by percentage of ownership occupied by national investors), ACM (composition of audit committee is defined as numbers of members formed from different wings of bank in audit committee), BS (Bank size is defined as total assets of the bank), BM (board meeting is define as the number of board meeting held in the given year), FD (female directors is define as the number of female director in the board).

The Table 3 showed that there is a positive relationship between board size and NPL of the commercial banks, which means larger the board, higher wouldbe the ratio of non-performing loan. Similarly, independent directors, audit committee member, domestic ownership, bank age, female director and bank size have also the positive relation with the ratio of non-performing loan. This indicates that more the independent directors on the board, higher would be the NPL. This indicates that more the audit committee member on the board, higher would be the NPL. This indicates that more the percentage of domestic ownership, higher would be the NPL. This indicates that older the bank, higher would be the NPL. This indicates that more the female directors on the board, higher would be the NPL. This indicates that larger the bank size, higher would be the NPL. Likewise, foreign ownership and CEO duality have negative relation with the ratio of NPL. This indicates that more the percentage of foreign ownership, lower would be the NPL. This also indicates that if the role of the CEO and board chairman is not separated, lower would be the NPL. 
Citation: Gupta AK, Wei GX (2018) Research on the Influence of Corporate Governance Structure on the Performance of Nepal Commercial Banks. J Glob Econ 6: 316. doi: 10.4172/2375-4389.1000316

Page 6 of 10

\section{Regression analysis}

The estimated regression result of firm's corporate governance variables on ratio of nonperforming loan is presented in Table 4. The results are based on panel data of 18 banks with 108 observations during the period 2010/11 to 2015/16, by using regression model. The model is, Efficiency $(E Y)=\beta_{0}+\beta_{1} B S+\beta 2$ ID $+\beta 3 A C M+\beta 4 F O+\beta 5 D O+\beta 6 C E O D+\beta 7$ $\mathrm{BA}+\beta 8 \mathrm{FD}+\beta 9 \mathrm{BM}+\beta 10 \mathrm{BAS}+\varepsilon \mathrm{it}$. Where, independent variables are $\mathrm{BS}$ (board size is defined as numbers of board members in a commercial bank), BM (board meeting is defined as numbers of board meeting held in a year), ID (independent directors is define as the number of independent director in the board),CEOD (CEO duality is define as the combination of responsibility of board chairperson and CEO), BAS (Bank age is defined as duration of operation till current year), FO (foreign ownership is defined as percentage of ownership occupied by foreign investors), DO (domestic ownership is define by percentage of ownership occupied by national investors), ACM (composition of audit committee is defined as numbers of members formed from different wings of bank in audit committee), BS (Bank size is defined as total assets of the bank),BM(board meeting is define as the number of board meeting held in the given year), FD (female directors is define as the number of female director in the board).

The result shows that beta coefficients are positive and significant for board size. This indicates that larger the board, higher would be the inefficiency of Nepalese commercial banks. The finding is consistent with the findings of Lipton and Lorsch, [20]. The result also shows that beta coefficients are positive and significant for board independence. This indicates that higher the number of independent member in the board, higher would be the inefficiency of Nepalese commercial banks. The finding is consistence with the finding of Anderson [19]. Similarly, beta coefficients are positive and significant for audit committee member. This indicate that larger the size of audit committee, higher would be the inefficiency of Nepalese commercial banks. The finding is opposite

\begin{tabular}{|c|c|c|c|c|c|c|c|c|c|c|c|}
\hline & EY & BS & ID & ACM & FO & DO & CEOD & BA & FD & BM & BAS \\
\hline EY & 1 & & & & & & & & & & \\
\hline BS & $0.315^{\star \star}$ & 1 & & & & & & & & & \\
\hline ID & $0.509^{* *}$ & $0.618^{* *}$ & 1 & & & & & & & & \\
\hline ACM & $0.547^{\star \star}$ & $0.233^{*}$ & $0.275^{* *}$ & 1 & & & & & & & \\
\hline FO & $-0.244^{\star}$ & $-0.366^{* *}$ & -0.175 & 0.096 & 1 & & & & & & \\
\hline DO & $0.259^{* *}$ & $0.311^{* *}$ & 0.134 & -0.115 & $-0.917^{\star *}$ & 1 & & & & & \\
\hline CEOD & -0.179 & $-0.353^{* *}$ & -0.099 & 0.041 & $0.669^{* *}$ & $-0.619^{* *}$ & 1 & & & & \\
\hline BA & $0.321^{\star \star}$ & -0.044 & 0.125 & $0.514^{* *}$ & $0.244^{\star}$ & $-0.475^{\star *}$ & 0.160 & 1 & & & \\
\hline FD & $0.298^{* *}$ & 0.144 & 0.132 & $0.293^{* *}$ & $0.195^{\star}$ & -0.162 & $0.195^{*}$ & $0.281^{* *}$ & 1 & & \\
\hline BM & $0.230^{*}$ & $0.337^{* *}$ & $0.341^{* *}$ & 0.109 & $-0.304^{* *}$ & $0.293^{* *}$ & -0.117 & -0.182 & -0.120 & 1 & \\
\hline BAS & $0.270^{\star *}$ & -0.019 & 0.032 & $0.586^{* *}$ & $0.317^{* *}$ & $-0.271^{\star *}$ & 0.029 & $0.535^{* *}$ & 0.125 & -0.144 & 1 \\
\hline
\end{tabular}

Table 3: Pearson correlation matrix for the selected Nepalese commercial banks.

\begin{tabular}{|c|c|c|c|c|c|c|c|c|c|c|c|c|c|c|}
\hline Mode & Intercept & BS & ID & ACM & FO & DO & CEOD & BA & FD & BM & BAS & $\begin{array}{l}\text { Adjusted } \\
\text { R2 }\end{array}$ & SEE & F-Value \\
\hline 1 & $\begin{array}{l}-1.343 \\
(-1.472)\end{array}$ & $\begin{array}{l}.388 \\
(3.412)^{\star *}\end{array}$ & & & & & & & & & & 0.090 & 1.548 & 11.641 \\
\hline 2 & $\begin{array}{l}-.564 \\
(-1.410)\end{array}$ & & $\begin{array}{l}.978 \\
(6.087)^{\star \star}\end{array}$ & & & & & & & & & 0.252 & 1.404 & 37.053 \\
\hline 3 & $\begin{array}{l}-2.673 \\
(-4.004)^{\star *}\end{array}$ & & & $\begin{array}{l}1.241 \\
(6.724)^{\star \star}\end{array}$ & & & & & & & & 0.292 & 1.365 & 45.213 \\
\hline 4 & $\begin{array}{l}1.955 \\
(11.134)^{\star \star}\end{array}$ & & & & $\begin{array}{l}-.018^{\star *} \\
(-2.595)^{\star *}\end{array}$ & & & & & & & 0.050 & 1.581 & 6.735 \\
\hline 5 & $\begin{array}{l}.221 \\
(0.391)\end{array}$ & & & & & $\begin{array}{l}.017 \\
(2.762)^{\star *}\end{array}$ & & & & & & 0.058 & 1.575 & 7.631 \\
\hline 6 & $\begin{array}{l}1.798 \\
(11.316)^{\star *}\end{array}$ & & & & & & $\begin{array}{l}-1.265 \\
(-1.876)\end{array}$ & & & & & 0.023 & 1.604 & 3.519 \\
\hline 7 & $\begin{array}{l}1.002 \\
(3.922)\end{array}$ & & & & & & & $\begin{array}{l}.040 \\
(3.489)^{\star *}\end{array}$ & & & & 0.094 & 1.544 & 12.171 \\
\hline 8 & $\begin{array}{l}1.458 \\
(8.487)^{\star \star}\end{array}$ & & & & & & & & $\begin{array}{l}.788 \\
(3.214)^{\star \star}\end{array}$ & & & 0.080 & 1.556 & 10.329 \\
\hline 9 & $\begin{array}{l}.997 \\
(2.953)^{\star *}\end{array}$ & & & & & & & & & $\begin{array}{l}.041 \\
(2.428)^{*}\end{array}$ & & 0.043 & 1.587 & 5.893 \\
\hline 10 & $\begin{array}{l}.958 \\
(3.123)^{\star \star}\end{array}$ & & & & & & & & & & $\begin{array}{l}.016 \\
(2.883)^{\star *}\end{array}$ & 0.063 & 1.570 & 8.309 \\
\hline 11 & $\begin{array}{l}-2.181 \\
(-2.378)^{*}\end{array}$ & $\begin{array}{l}.395 \\
(3.608)^{\star *}\end{array}$ & & & & & & & & & $\begin{array}{l}.016 \\
(3.110)^{\star *}\end{array}$ & 0.159 & 1.488 & 11.133 \\
\hline 12 & $\begin{array}{l}-3.445 \\
(-5.333)^{* *}\end{array}$ & & $\begin{array}{l}.748 \\
(5.100)^{\star *}\end{array}$ & $\begin{array}{l}.925 \\
(4.618)^{\star *}\end{array}$ & & & & $\begin{array}{l}.008 \\
(0.734)^{\star *}\end{array}$ & & & & 0.424 & 1.231 & 27.343 \\
\hline 13 & $\begin{array}{l}-.758 \\
(-0.551)\end{array}$ & & & & $\begin{array}{l}-.019 \\
(-1.252)\end{array}$ & $\begin{array}{l}.008 \\
(0.582)\end{array}$ & & & $\begin{array}{l}.916 \\
(4.217)^{\star *}\end{array}$ & $\begin{array}{l}.038 \\
(2.504)^{*}\end{array}$ & $\begin{array}{l}.022 \\
(4.358)^{\star *}\end{array}$ & 0.3127 & 1.345 & 10.740 \\
\hline
\end{tabular}

${ }^{* *}$ Correlation is significant at the 0.01 level (2-tailed)

${ }^{*}$ Correlation is significant at the 0.05 level (2-tailed).

Table 4: Regression of corporate governance and dependent variable of efficiency. 
Citation: Gupta AK, Wei GX (2018) Research on the Influence of Corporate Governance Structure on the Performance of Nepal Commercial Banks. J Glob Econ 6: 316. doi: 10.4172/2375-4389.1000316

Page 7 of 10

with the finding of Pathak and Zigli [31]. Furthermore, the result shows that beta coefficients are negative and significant for foreign ownership. This indicates that higher the proportion of foreign ownership in the commercial bank, higher would be the efficiency of the commercial bank of Nepal. The result is consistent with the finding of Clarke et al. [45]. Just opposite of it the result shows that beta coefficients are positive and significant for domestic ownership. This indicates that higher the proportion of domestic ownership, higher would be the inefficiency of Neplese commercial banks. The finding is similar to Porta and et al. [46]. Moreover, the result also shows that beta coefficients of CEO duality is negative. This indicates that if role of the board chair person and CEO is not separated, there would be the higher efficiency of the Nepalese commercial bank. The finding is consistence with the finding of Daily and Dalton [49]. The result also shows that beta coefficients are positive and significant for bank age. This indicates that older the bank, higher would be the inefficiency of Nepalese commercial banks. The finding is consistence with the finding of Majudmar [71]. The result also shows that beta coefficients are positive and significant for female directors. This indicates that increase in number of female director in the board, higher would be the inefficiency of Nepalese commercial banks. This finding is opposite to finding of Ibarra [57]. Furthermore, the result shows that beta coefficients are positive and significant for board meeting. This indicates that higher the board meeting, higher would be the inefficiency of Nepalese commercial bank. The finding is opposite with the finding of Jensen and Meckling [4]. The result also showed that beta coefficients are positive and significant for bank size. This indicates that larger the size of the bank, higher would be the inefficiency of Nepalese commercial bank. The finding is opposite to finding with the Deis and Guffey [69].

(The results are based on panel data of 18 banks with 108 observations during the period
2010/11 to 2015/16, by using regression model. The model is, cost efficiency $=\beta_{0}+\beta_{1} \mathrm{BS}+\beta_{2} \mathrm{ID}$

$+\beta 3 \mathrm{ACM}+\beta 4 \mathrm{FO}+\beta 5 \mathrm{DO}+\beta 6 \mathrm{CEOD}+\beta 7 \mathrm{BA}+\beta 8 \mathrm{FD}+\beta 9 \mathrm{BM}+\beta 10 \mathrm{~B}$ $\mathrm{AS}+$ Eit. Where, independent variables are BS (board size is defined as numbers of board members in a commercial bank), BM (board meeting is defined as numbers of board meeting held in a year), ID (independent directors is define as the number of independent director in the board),CEOD (CEO duality is define as the combination of responsibility of board chairperson and CEO), BAS (Bank age is defined as duration of operation till current year), FO (foreign ownership is defined as percentage of ownership occupied by foreign investors), DO (domestic ownership is define by percentage of ownership occupied by national investors), ACM (composition of audit committee is defined as numbers of members formed from different wings of bank in audit committee), BS (Bank size is defined as total assets of the bank), BM (board meeting is define as the number of board meeting held in the given year), FD(female directors is define as the number of female director in the board).

The Table 5 shows that the beta coefficient is negative for independent director. This result indicates that greater the independent director in the board lower would be the cost of the commercial bank [72]. The result also shows that beta coefficient is positive for audit committee member. This result indicates that higher the number of auditee member in the auditee committee team higher will be the cost efficiency. The result shows that beta coefficient of are negative for foreign ownership. This result indicates that higher the proportion of foreign ownership lower would be the cost efficiency of the commercial bank. The result shows that beta coefficient for domestic's ownership is positive [73-75]. This result indicates that higher the proportion of domestic's ownership higher would be the cost efficiency of the commercial bank. The result also shows that beta coefficient of bank age are negative relation with bank age. This indicates that older the

\begin{tabular}{|c|c|c|c|c|c|c|c|c|c|c|c|c|c|c|}
\hline Mode & Intercept & BS & ID & ACM & FO & DO & CEOD & BA & FD & BM & BAS & $\begin{array}{l}\text { Adjusted } \\
\text { R2 }\end{array}$ & SEE & F-Value \\
\hline 1 & $\begin{array}{l}0.121 \\
(2.014)^{*}\end{array}$ & $\begin{array}{l}-0.004 \\
(-.562)\end{array}$ & & & & & & & & & & 0.003 & 0.102 & 0.316 \\
\hline 2 & $\begin{array}{l}0.141 \\
(4.942)^{\star \star}\end{array}$ & & $\begin{array}{l}-0.023 \\
(-1.988)^{*}\end{array}$ & & & & & & & & & 0.027 & 0.101 & 3.950 \\
\hline 3 & $\begin{array}{l}0.086 \\
(1.727)\end{array}$ & & & $\begin{array}{l}0.000 \\
(.031)\end{array}$ & & & & & & & & 0.000 & 0.102 & 0.001 \\
\hline 4 & $\begin{array}{l}0.100 \\
(9.044)^{\star *}\end{array}$ & & & & $\begin{array}{l}-0.001 \\
(-2.253)^{*}\end{array}$ & & & & & & & 0.037 & 0.099 & 5.075 \\
\hline 5 & $\begin{array}{l}0.004 \\
(.104)\end{array}$ & & & & & $\begin{array}{l}0.001 \\
(2.253)^{*}\end{array}$ & & & & & & 0.037 & 0.099 & 5.075 \\
\hline 6 & $\begin{array}{l}0.091 \\
(9.071)^{\star *}\end{array}$ & & & & & & $\begin{array}{l}-0.058 \\
(-1.360)\end{array}$ & & & & & 0.008 & 0.102 & 1.848 \\
\hline 7 & $\begin{array}{l}0.088 \\
(4.566)^{\star *}\end{array}$ & & & & & & & $\begin{array}{l}-0.000021 \\
(-.022)\end{array}$ & & & & 0.000 & 0.103 & 0.000 \\
\hline 8 & $\begin{array}{l}0.087 \\
(7.703)^{\star *}\end{array}$ & & & & & & & & $\begin{array}{l}0.003 \\
(.173)\end{array}$ & & & -0.009 & 0.102213 & 0.030 \\
\hline 9 & $\begin{array}{l}0.095 \\
(4.384)^{\star *}\end{array}$ & & & & & & & & & $\begin{array}{l}0.000 \\
(-.383)^{\star *}\end{array}$ & & -0.008 & .102157 & .146 \\
\hline 10 & $\begin{array}{l}0.111 \\
(5.578)^{\star \star}\end{array}$ & & & & & & & & & & $\begin{array}{l}0.000 \\
(-1.339)\end{array}$ & 0.007 & .101374 & 1.792 \\
\hline 11 & $\begin{array}{l}0.001 \\
(.014)\end{array}$ & $\begin{array}{l}-0.001 \\
(-0.138)\end{array}$ & $\begin{array}{l}-0.031 \\
(-2.096)\end{array}$ & $\begin{array}{l}0.015 \\
(1.055)\end{array}$ & & $\begin{array}{l}001 \\
(2.283)\end{array}$ & $\begin{array}{l}0.014 \\
(.244)\end{array}$ & & & & . & 0.065 & 0.098368 & 2.496 \\
\hline 12 & $\begin{array}{l}0.103 \\
(1.973)^{*}\end{array}$ & & & $\begin{array}{l}-0.005 \\
(-.315)\end{array}$ & $\begin{array}{c}-0.001 \\
(-1.956)\end{array}$ & . & $\begin{array}{l}0.010 \\
(.181)\end{array}$ & $.001(.849)$ & & & & 0.016 & 0.100910 & 1.446 \\
\hline 13 & $\begin{array}{l}0.018 \\
(.202)\end{array}$ & $\begin{array}{l}0.002 \\
(.183)\end{array}$ & $\begin{array}{l}-0.036 \\
(2.367)^{\star}\end{array}$ & $\begin{array}{l}0.019 \\
(1.012)\end{array}$ & & $\begin{array}{l}0.001 \\
(1.540)\end{array}$ & $\begin{array}{l}-0.029 \\
(-.475)\end{array}$ & $\begin{array}{c}0.003 \\
(1.758)\end{array}$ & $\begin{array}{l}-0.002 \\
(-.091)\end{array}$ & $\begin{array}{l}0.000 \\
(-.187)\end{array}$ & $\begin{array}{l}-0.001 \\
(-2.157)^{\star}\end{array}$ & .082 & $\begin{array}{l}0.097 \\
506\end{array}$ & 2.057 \\
\hline
\end{tabular}

${ }^{* *}$ Correlation is significant at the 0.01 level (2-tailed)

${ }^{*}$ Correlation is significant at the 0.05 level (2-tailed).

Table 5: Regression of corporate governance and dependent variable of cost efficiency 
bank higher would be the cost efficiency. Similarly, the beta coefficient is positive for female director. This result indicates that if there is large number of female director in the board, there would be higher cost efficiency [76-82].

\section{Summary and Conclusion}

Corporate governance has a relationship pattern between management with its stakeholders, management and board of directors. This relationship is based on ethics, corporate culture and corporate value and supported by system, process, working procedures and organization; in achieving maximum performance [83]. Nonperforming loan is an important subject for the corporate body. It shows the efficiency and effectiveness of the organization. This study attempts to examine the effect of corporate governance variables on the nonperforming loan to assets. This study is based on secondary data of 18 commercial banks with 108 observations for the period of 2010/11 to $2015 / 16$ [84-88].

The major conclusion of the study is that board size has positive relation with the ratio of nonperforming loan, which designates that larger the size of board of governor more would be the ratio of nonperforming loan and hence the bank efficiency will be lower [89-91]. The current result also determines that number of director (independent) has positive relation with the ratio of non-performing loan, which described that, more number of independent director in the board of governor, will make more the ratio of non-performing loan and less will be the efficiency of the commercial bank. Similarly audit committee member has also positive relation with the ratio of non- performing loan i.e. more audited member in the audit committee would increase the ratio of non-performing loan and efficiency of bank would decrease. The result also show that the presence of foreign ownership in board of governor has negative relation with the ratio of non-performing loan, which shows that the higher presence of foreigner lower the ratio of nonperforming loan which would otherwise increase the commercial bank efficiency. Moreover, the result also specify that domestic ownership has positive relation with the ratio of non-performing loan which show that greater the percentage of domestic ownership in the commercial bank greater would be the ratio of non-performing loan which would otherwise lower the efficiency of commercial bank [92-94]. The result also show that CEO duality has negative relation with the ratio of nonperforming loan which describes that the ratio of non-performing loan will be decrease, hence which would increase the commercial bank. The result also indicate that bank age has positive relation with the ratio of non-performing loan hence older the bank higher would be the ratio of non-performing loan, which would decrease the efficiency of the bank. The presence of number of female director in the board of governor and number of meeting in the given year have positive relation with the ratio of non-performing loan, which described that more quantity of female directors in the board with more meeting would result to increase the ratio of non-performing loan and decrease the efficiency of the bank. Similarly the bank size has also positive relation with the ratio of non- performing loan, which indicate that larger the size of the bank with respect to the total assets advanced will be the ratio of nonperforming loan, hence lower would be the bank efficiency. The current scientific research conducted under the Federal demo Republic of Nepal commercial banking environment, which shows that it is affect the acceptance of practicing good corporate governance. According to authors the principle of corporate governance in developing countries are resulting from the reference in developed countries, so that if the principles are suitable in developed countries, it is not vital to be suitable in under developed countries. The objectives of current work is examining the impact of corporate governance mechanism i.e. board size and independence, audit committee size and diligence and ownership structure in the performance of banking industry in Nepal $[95,96]$. The study pays to the current literature from different perspective. Numerous revisions have been done in context of developed economies however study regarding corporate governance and bank efficiency is scare to non-existed in context of developing countries. So, the work is trying to tie the gaps in the research of relationship between corporate governance mechanism and bank performance in Nepal. Moreover, the study cover 18 commercial banks operated in Nepal out of 28 commercial banks. The study covers covered more recent period, the year 2010/11-2015/16, when most of the regulatory decisions were taken by the central bank of Nepal for the corporate governance. The current study finding will improve and enhance the banking sector because it is important implication for bank in Nepal since it is found that strong board size and audit committee size and higher proportion of independent director in audit committee, lower frequency of board meeting and lower ratio of institutional ownership has better influence in Nepalese banks. The limitation of this study is that it relies only on financial accounting report. Financial account reports suffer from the following errors: are subject to manipulation may systematically undervalue assets; produces alterations due to the nature of depreciation method implemented, method of inventory valuation, and treatment of certain revenue and expenditure items. Next, the study considers data of only six years. The result may differ if multiple years are considered for analysis. Based on the study, other corporate governance mechanism not studied in this research has a very significant contribution to banks' efficiency. Therefore, regarding future line of research, effort should be put at increasing the sample size, year size and the corporate governance variables, particularly in case of board: board expertise, board tenure. Similarly in case of ownership structure: ownership concentration, ownership mix. We hope that, these limitations do not compromise on the validity of conclusion drawn based on the result.

\section{References}

1. Yung MF (2009) The relationship between corporate governance and bank performance in Hong Kong (Doctoral dissertation, Auckland University of Technology).

2. Wepukhulu JM (2016) Relationship between Corporate Governance and Performance of Commercial Banks in Kenya (Doctoral dissertation).

3. Poudel RP, Hovey M (2013) Corporate governance and Efficiency in Nepalese Commercial Banks. Int Rev Bus Res Pap 9: 53-64

4. Jensen MC, Meckling WH (1976) Theory of the firm: Managerial behavior agency costs and ownership structure. J Financ Econ 3: 305-360.

5. Tornyeva K, Wereko T (2012) Corporate Governance and Firm Performance: Evidence from the Insurance. Eur J Bus Manage 4: 95-112.

6. Wanyama DW, Olweny $T$ (2013) Effects of corporate governance on financia performance of listed insurance firms in Kenya. Public policy adm rese 3: 96-120.

7. Padilla A (2002) Can agency theory justify the regulation of insider trading? $Q$ J Austrian Econ 5: 3-38.

8. Clarke T (2004) Theories of corporate governance. PhiloFound Corp Gov.

9. Eagly A, Johnson B (1990) Gender and leadership style: A meta-analysis Psychological Bulletin. 108: 233-256. In: Sanchez EY, Gonzalez J (1998) Sexual differences in management styles in public administration 141-154.

10. Jensen MC (2001) Value maximization, stakeholder theory, and the corporate objective function. J Appl Corp Financ 14: 8-21.

11. Donaldson T, Preston LE (1995) The stakeholder theory of the corporation Concepts, evidence, and implications. Acad manage Rev 20: 65-91.

12. Yoshikawa T, Phan PH (2003) The performance implications of ownershipdriven governance reform. Eur Manage J 21: 698-706. 
Citation: Gupta AK, Wei GX (2018) Research on the Influence of Corporate Governance Structure on the Performance of Nepal Commercial Banks. J Glob Econ 6: 316. doi: 10.4172/2375-4389.1000316

13. Bussoli C, Gigante M, Tritto MB (2015) The Impact of Corporate Governance on Banks Performance and Loan Quality: Evidence From Italian Cooperative Banks. Chin Bus Rev 14: 390-401.

14. Agoraki ME, Manthos D Delis, Staikouras $P$ (2009) The effect of board size and composition on bank efficiency. Int J Bank Account Financ.

15. Simpson WG, Gleason AE (1999) Board structure, ownership, and financial distress in banking firms. Int Rev Econ Financ 8: 281-292.

16. Belkhir M (2006) Board structure, ownership structure, and firm performance: evidence from banking. Appl Financ Econ 19: 1581-1593.

17. Altunbas Y, Gardener EPM, Molyneux P, Moore B (2001) Efficiency in European banking. Eur Econ Rev 45: 1931-1955

18. Anderson CW, Campbell TL (2004) Corporate governance of Japanese banks J Corp Financ 10: 327-354.

19. Jensen MC, Ruback RS (1983) The market for corporate control: The scientific evidence. J Financ Econ 11: 5-50.

20. Lipton M, Lorsch JW (1992) A modest proposal for improved corporate governance. Bus lawyer 48: 59-77.

21. Zahra SA, Pearce JA (1989) Boards of directors and corporate financial performance: A review and integrative model. J manage 15: 291-334.

22. Ghabayen MA (2012) Board characteristics and firm performance: Case of Saudi Arabia. Int J Account Financ Rep 2: 168

23. Cladera CR, Gispert C (2003) Total board compensation, governance and performance of Spanish listed companies. Labour, 17: 103-126.

24. Raheja CG (2005) Determinants of board size and composition: A theory of corporate boards. J Financ Quant Anal 40: 283-306.

25. Harris M, Raviv A (2008) A theory of board control and size. Rev Financ Stud 21: $1797-1832$

26. Adams R, Mehran H (2003) Is corporate governance different for bank holding companies. Econ Policy Rev 9: 123-142.

27. Fama EF (1980) Agency Problems and the Theory of the Firm. J political econ 88: $288-307$

28. Fama E, Jensen M (1983) Separation of ownership and control. J Law Econ 26: 301-325.

29. Pincus K, Rusbarsky M, Wong J (1989) Voluntary formation of corporate audit committees among NASDAQ firms. J account public policy 8: 239-265.

30. Al-Smadi MO (2013) Examining the Relationship between Corporate Governance and Banks' Performance, and Risk in Saudi Arabia. Eu J Econ, Financ Adm Sci 59: 1-17.

31. Burton GE, Pathak DS, Zigli RM (1976) The effects of organizationa communication on job satisfaction and motivation factors for management. $J$ manage 2: 17-23.

32. Klein A (2002) Audit committee, board of director characteristics, and earnings management. J Account Econ 33: 375-400.

33. Hardwick P, Adams MB, Hong Z (2003) Corporate governance and cos efficiency in the United Kingdom life insurance industry. European Business Management School, University of Wales, Swansea.

34. Coleman KA (2008) Corporate governance and firm performance in Africa: A dynamic panel data analysis. Stud Econ Econom 32: 1-24.

35. Kajola SO (2008) Corporate governance and firm performance: The case of Nigerian listed firms. Eur J Econ Financ Adm Sci14: 1628.

36. Levine R (1996) Foreign banks, financial development, and economic growth In: Claude EB. (Ed) Int Financ Mark AEI Press, Washington, DC.

37. Brealey RA Kaplanis EC (1996) The determination of foreign banking location $\mathrm{J}$ Int Money Financ 15: 577-97.

38. Lensink R, Hermes N (2004) The short-term effects of foreign bank entry on domestic bank behaviour: does economic development matter? J Bank Financ 28: 553-68.

39. Barth JR, Dopico LG, Nolle DE, Wilcox JA (2002) Bank safety and soundness and the structure of bank supervision: a cross-country analysis. Int Rev Financ 3: $163-88$
40. Boubakri N, Cosset JC, Guedhami O (2005) Postprivatization corporate governance: the role of ownership structure and investor protection. J Financ Econ 76: 369-99.

41. Micco A, Panizza U, Yanez M (2004) Bank ownership and performance. Working Paper, No. 518, Inter-American Development Bank, Washington, DC.

42. Shleifer A, Vishny RW (1997) A survey of corporate governance. J finance 52 737-783.

43. Gorg H, Greenaway D (2004) Much ado about nothing? Do domestic firms really benefit from foreign direct investment? World Bank Res Obs 19: 171-197.

44. Bonin JP, Hasan I, Wachtel P (2005) Bank performance, efficiency and ownership in transition countries. Journal of Banking \& Finance 19: 31-53.

45. Clarke G, Cull R, D Amato L, Molinari A (1999) The effect of foreign entry on Argentina's domestic banking sector. Policy Research Working Paper Argentina.

46. Porta LR, Silanes LDF, Zamarripa G (2003) Related lending. Q J Econ 118 231-268.

47. Abdullah NS (2004) Board composition CEO duality and performance among Malaysian listed companies. Corporate Gov Int J Bus Soc 4: 47-61.

48. Chaarani EH (2014) The impact of corporate governance on the performance of Lebanese banks. The International J Bus Financ Res 8: 35-46.

49. Daily CM, Dalton DR (1993) Board of directors leadership and structure: Control and performance implications. Entrep Theory Prac 17: 65-82.

50. Yuan CY, Michael N, Young (2010) Cross-border mergers and acquisitions by Chinese listed companies: A principal-principal perspective. Asia Pac J Manage 27: 523-539.

51. Yermack D (1996) Higher market valuation of companies with a small board of directors. J financ econ 40: 185-211.

52. Ehikioya BI (2009) Corporate governance structure and firm performance in developing economies: evidence from Nigeria. Corp Gov Int J Bus Soc 9: 231 243.

53. Coad AA, Segarra, Teruel M (2013) Like milk or wine: Does firm performance improve with age?. Struct Chang Econ Dyn 24: 173-189.

54. Ikram A, Su Q, ljaz F, Fiaz M (2016) Determinants Of Non-Performing Loans: An Empirical Investigation Of Bank-Specific Microeconomic Factors. J App Bus Res (JABR) 32: 1723-1736.

55. Stierwald A (2009) Determinants of firm profitability-the effect of productivity and its persistence. Melb Inst of Appl Econ Soc Res.

56. Adams, Renee B, Funk, Patricia C (2012) Beyond the Glass Ceiling: Does Gender Matter?. Manage Sci 58: 219-235

57. Virtanen A (2012) Women on the boards of listed companies: Evidence from Finland. J Manage Gov 16: 571-593.

58. Ibarra H (1992) Homophily and differential returns: Sex differences in network structure and access in an advertising firm. Adm sci Q 2: 422-447.

59. Eagly AH (1978) Sex differences in social behavior: A social-role interpretation. Hillsdale, NJ, Hillsdale, NJ: Lawrence Erlbaum, US.

60. Rosener JB (1995) America's competitive secret: Utilizing women as a power strategy.

61. Balina R (2017) Does the Gender of a Bank's President Have an Effect on Financial Performance? A Case Study of Poland's Cooperative Bank Sector. J Corp Resp Leadersh 3: 9-22.

62. Lai PF, Choi ON (2014) Corporate Governance and Financial Performance of Bank in Asian Regions and Recommendations. Asian J Financ Account 6 : 377-406.

63. Marimuthu M (2008) Ethnic Diversity on Boards of Directors and Its Implications on Firm Financial Performance. J Int Soc Res 1: 431-445.

64. Jensen MC (1993) The modern industrial revolution, exit, and the failure of internal control systems. J Financ 48: 31-80.

65. Pandey IM (2004) Capital structure, profitability and market structure: Evidence from Malaysia. The Asia Pacific J Econ Buss 8: 78-91.

66. Pasiouras F, Sifodaskalakis E, Zopounidis C (2007) Estimating and analysing 
Citation: Gupta AK, Wei GX (2018) Research on the Influence of Corporate Governance Structure on the Performance of Nepal Commercial Banks. J Glob Econ 6: 316. doi: 10.4172/2375-4389.1000316

Page 10 of 10

the cost efficiency of Greek cooperative banks: an application of two-stage data envelopment analysis. University of Bath Working Paper, 2: 3-15.

67. Hauner D (2005) Explaining efficiency differences among large German and Austrian banks. Appl Econ 37: 969-980.

68. Ammar A, Hanna AS, Nordheim EV, Russell JS (2003) Indicator variables model of firm's size-profitability relationship of electrical contractors using financial and economic data. J Const Eng Manage 129: 192-197.

69. Deis DR, Guffey DM, Moore WT (1995) Further evidence on the relationship between bankruptcy costs and firm size. Q J Bus Econ 69-79.

70. Majumdar SK (1997) The impact of size and age on firm-level performance: some evidence from India. Rev Ind Organ12: 231-241.

71. Allan P, Widman A (2000) A comparison of the views of CEOs and public pension funds on the corporate governance ssues of chairman-CEO duality and election of lead directors. Am Bus Rev 18: 49-54.

72. Bilimoria D, Wheeler JV (2000) Women corporate directors: Current research and future directions. Women in management: Current research issues 2 : 138-163.

73. Brealey RA Kaplanis EC (1996) The determination of foreign banking location. J Int Money Financ 15: 577-97.

74. Chaganti RS, Mahajan V, Sharma S (1985) Corporate board size, composition and corporate failures in retailing industry. J Manage Stud 22: 400-417.

75. Charkham J (1994) Keeping Good Company: A Study of Corpor-ate Governance in Five Countries. Clarendon Press, Oxford

76. DeZoort FT, Hermanson DR, Archambeault DS, Reed SA (2002) Audit committee effectiveness: A synthesis of the empirical audit committee literature. $\mathrm{J}$ Account lit 21: 38-75.

77. Fosberg RH (2004) Agency problems and debt financing: leadership structure effects. Corp Gov Int J Bus Soc 4: 31-38.

78. Gerlach ML (1992) Alliance capitalism: Th0065 social organization of Japanese business. Univ of California Press.

79. Hsu HE (2007) Boards of directors and audit committees in initial public offerings. Pro Quest.

80. In EB, Lancry A, Louche C, Eagly AH (1987) Sex differences in social behavior: A social-role interpretation. Am Psuchol Assoc.

81. Ingley C, Walt VDN (2005) Do board processes influence director and board performance? Statutory and performance implications. Corp Gov Int Rev 13 632-653.

82. Kang JK, Shivdasani A (1995) Firm performance, corporate governance, and top executive turnover in Japan. J Financ Econ 38: 29-58.

83. Kikuchi M (1999) Kigyokachihyokakakumei (Revolution in corporate valuation). Tokyo: Toyo Keizai Shimposha.

84. Kosnik RD (1987) Greenmail: A study of board performance in corporate governance. Adm Sci Q 32: 163-185.

85. Laeven L (2001) Insider lending and bank ownership: The case of Russia. J Comp Econ 29: 207-229.

86. Menon K, Williams JD (1994) The use of audit committees for monitoring. J Account Public Policy 13: 121-139.

87. Mak YT, Li Y (2001) Determinants of corporate ownership and board structure: evidence from Singapore. J Corp Financ 7: 235-256.

88. Xie B, Davidson WN, DaDalt PJ (2003) Earnings management and corporate governance: the role of the board and the audit committee. $\mathrm{J}$ corp financ 9 : 295-316.

89. Stiles $P$ (2001) The impact of the board on strategy: An empirical examination. J Manage Stud 38: 627-650.

90. Singh H, Harianto $F(1989)$ Management-board relationships, takeover risk and the adoption of golden parachutes. Acad Manage J 32: 7-24.

91. Sigdel BR, Koirala S (2015) Corporate governance in nepalese financial sector does policy matter.

92. Lin JW, Li JF, Yang JS (2006) The effect of audit committee performance on earnings quality. Manage Audit J 21: 921-933.

93. Pan Y, Sparks JR (2012) Predictors, consequence, and measurement of ethical judgments: Review and meta-analysis. J Bus Res 65: 84-91.

94. Sheard P (1997) Mein Banku Shihonshugi no Kiki (Crisis of the main bank capitalism). Tokyo, Toyo Keizai Shimposha.

95. Schellenger MH, Wood DD, Tashakori A (1989) Board of director composition, shareholder wealth, and dividend policy. J Manage 15: 457-467.

96. Pfeifer J, Salancik G (1978) The External Control of Companies: A Resource Dependence Perspective. 